\section{Recurrent of aphthous stomatitis (RAS) and exfoliative cheilitis in elderly psoriasis sufferer}

\author{
Siti H. Nurhasanah, ${ }^{1}$ Astrid Palmasari, ${ }^{1}$ Dwi Setyaningtyas, ${ }^{1}$ Sujati, ${ }^{2}$ \\ Okty Setyawati²
}

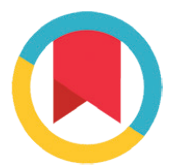

CrossMark

\title{
Abstract
}

Objective: Recurrent aphthous stomatitis (RAS) is a disorder in the oral cavity characterized by symptoms such as: ulceration, recurrent and very painful. The etiology is idiopathic, with multifactorial predisposition. Exfoliative cheilitis is a persistent lesion on the lip characterized by cracking and desquamative with crustae and inflammation.

Methods: An elderly male (72 years old) had suffered ulcer on his oral cavity with, cracking lips and pain on both of his cheeks and skin for 5 years. The pain was recurrent. On the clinical examination, there were some desquamations, both on the skin and vermilion border and on the inner lips (labial fold mucosa), there were ulcers with diameter about $1 \mathrm{~cm}$.

Results: The laboratory test was within normal limits, except the LED was $40 \mathrm{~mm} /$ hour $(\mathrm{n}:<15)$. The diagnosis was recurrent aphthous stomatitis for the ulcer and exfoliative cheilitis for the cracking lips. The treatment he received was a gargle liquid, topical corticosteroid and supplement.

Conclusion: We have to be very careful and familiar to every change that may occur both in the outer or inner oral cavity. Other disorder that needs referral, had to be done with team work, to the colleague from the right connection.
${ }^{1}$ Faculty of Dentistry, Hang Tuah University, Surabaya, Indonesia ${ }^{2}$ Faculty of Dentistry, Airlangga University, Surabaya, Indonesia

"Correspondence to: isidora.karsini.drg@gmail.com

Received: 16 March 2016

Revised: 25 April 2016

Accepted: 26 April 2016

Available Online: 30 April 2016

Keywords: Ulcer, Recurrent, Desquamation, Pain

Cite this Article: Nurhasanah SH, Palmasari A, Setyaningtyas D, Sujati, Setyawati 0. 2016. Recurrent of Aphthous Stomatitis (RAS) and exfoliative cheilitis in elderly psoriasis sufferer. Journal of Dentomaxillofacial Science 1(1): 63-66. D01:10.15562/jdmfs.v1i1.29

\section{Introduction}

Recurrent aphthous stomatitis (RAS) (also referred to as aphthae or canker sores) is one of the most common oral ailments. The disease is characterized by recurring painful ulcers of the mouth that are round or ovoid and have inflammatory halos. ${ }^{1}$ Three clinical presentations of RAS are recognized: minor recurrent aphthous stomatitis, major recurrent aphthous stomatitis and herpetiform ulceration. ${ }^{2}$ The cause of RAS has not known for sure but it is possibility multifactorial. Several factors which are considered as the cause of the RAS include: congenital factors, trauma, infection associated with gastrointestinal disorders, influence of hormones, emotional factors, auto-immunity, hematologic factors and etc. ${ }^{3}$

Exfoliative cheilitis is an uncommon condition affecting only the vermillion border of the lips and characterized by chronic inflamed, crusted and sometimes fissured. Etiology and pathogenesis are unknown: however, some cases are associated with stress. People with this condition may have some degree of pain and difficulty speaking, eating or smiling. Although exfoliative cheilitis may resolve spontaneously, it often appears periodically and can persist for years. ${ }^{2,4,5}$

Psoriasis is a common chronic inflammatory, immune-mediated disease that predominantly affects the skin and joints. ${ }^{6,7}$ Plaque psoriasis is the most common form. Psoriatic plaque appears as raised, red patches covered with a silvery white buildup of dead skin cells. Psoriasis can occur on any part of the body and is associated with other serious health conditions, such as diabetes, heart disease and depression., ${ }^{7,8}$ This case report describes a patient suffering from three diseases simultaneously.

\section{Case Report}

Figure 1 shows a male patient, 72 years old came to the Hospital at the University of Hang Tuah with complaint of cancer sores in the mouth cavity and dried lips with pain on the outer left and right cheek, since years ago. With recurrent pain. Based on clinical examination, outer cheeks and lips look desquamated, while on the inside there was a lip ulcer with a diameter of approximately $1 \mathrm{~cm}$. The patient complained of difficulty in eating and smiling.

Figure 2 based on the history and the clinical examination was diagnosed with major RAS with exfoliative cheilitis. On the first visit the patient was given a prescription mouthwash to improve oral hygiene, topical corticosteroids, supplements, and referral to perform a complete blood count and 

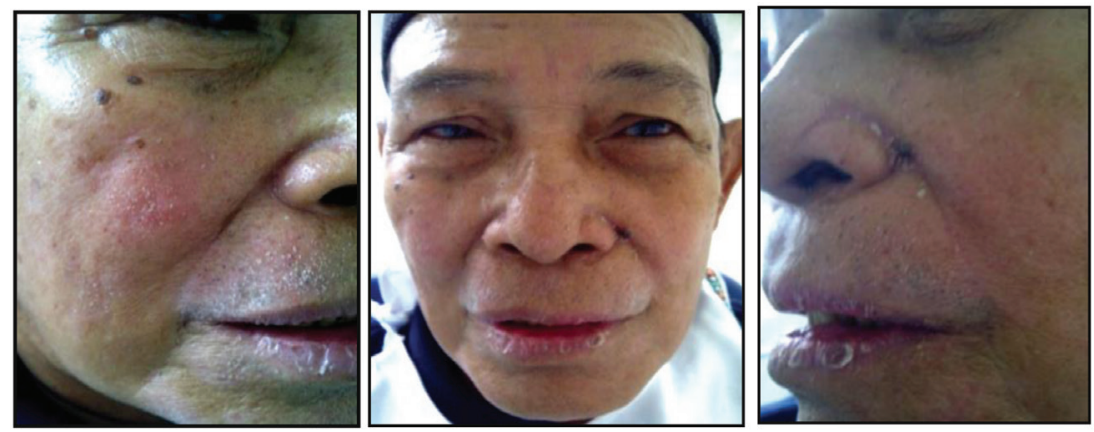

Figure 1 Extra-oral clinical photos before treatment

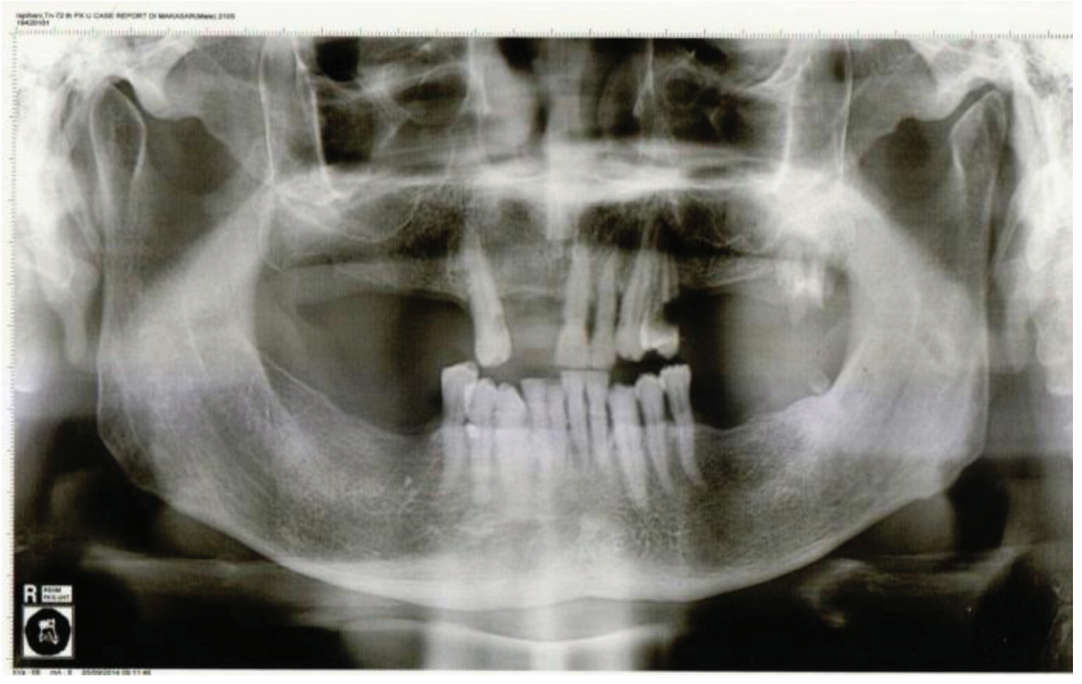

Figure 3 Panoramic photo

\begin{tabular}{|c|c|c|c|c|c|}
\hline PEMERIKSAAN & HASIL & 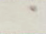 & NILAI NORMAL & SATUAN & KETERANGAN \\
\hline HEMATOLOGI & & & & & \\
\hline DARAH LENGKAP (AUTOMATIC) & & . & & & \\
\hline Hemoglobin & 14.1 & & L.13,5-18.0 P. $11,5-16,0$ & g/dl & \\
\hline Lekosit & 7700 & & $3.500-10.000$ & $/ \mathrm{cmm}$ & \\
\hline LED & $* 40$ & & $L<15$ P $<20$ & mm/jam I & \\
\hline Hitung Jenis: & & & & & \\
\hline Eosinofil & & & 1.2 & $\%$ & \\
\hline Basofil & - & & $0-1$ & $\%$ & \\
\hline Stab & . & & 3.7 & $\%$ & \\
\hline Segmen & $* 53$ & & $54-62$ & $\%$ & \\
\hline Limfosit & 37 & & $17-48$ & $\%$ & \\
\hline Monosit & 10 & & $4-10$ & $\%$ & \\
\hline Trombosit & 306000 & & $150.000-390.000$ & $/ \mathrm{mm} 3$ & \\
\hline Hematokrit & * 38.3 & & {$[.40-54 \quad$ P. $35-47$} & $\%$ & \\
\hline ALERGI & & & & & \\
\hline IgE TOTAL & 63.53 & & $k 100$ & IU/ml & \\
\hline
\end{tabular}

Figure 4 Laboratories test results

panoramic photos. Figure 3 the results of panoramic photos showed no abnormalities.

Laboratories test results were all within normal limits, except for neutrofil segmen (neutrophil; 53, 54-62), hematocrit $38.3(40-54)$, LED $40(<15)$ so that referral to a specialist in genital skin for further examination related to abnormalities in the outer cheek.

Figure 4 the result of a referral from a specialist skin and genital department stated that the patient was suffering from psoriasis so that the necessary

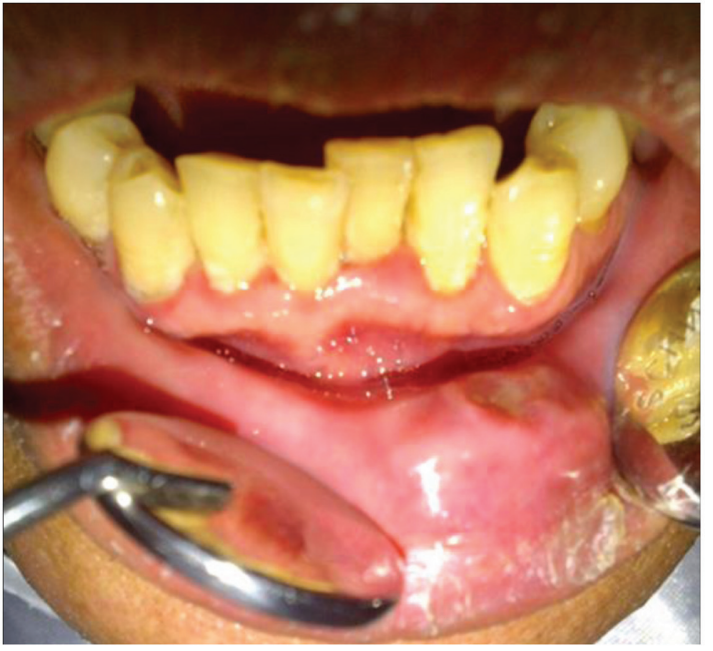

Figure 2 Clinical intra-oral photos

prescription was given to overcome the complaint in cheek.

\section{Discussion}

In the case of patient's suffering from RAS major types with clinical features oval, diameter $1 \mathrm{~cm}$, single and very painful that appear on the inside of the lip mucosa. In this case RAS major types was settled for 1 week and left scars when healed.

Laboratories blood test results all within normal limits, except for neutrofil segmen 53 (54-62), hematocrit 38.3 (40-54), LED (Erythrocyte sedimentation rate) $40(<15)$. LED increased to more than normal showed acute or chronic conditions. The decrease in hematocrit value was an indicator of anemia. Decrease in the percentage of neutrophils, can be caused by decreased production of neutrophils, increased cell damage, infections, and hormonal disorders. ${ }^{9}$

A panoramic photograph showed that the patient's need for removable partial denture to repair masticatory function after treatment for RAS, Exfoliative cheilitis and psoriasis had been done.

The cause of the RAS is not known with certainty but is probably multifactorial. Several factors are considered as the cause of the RAS include: heredity, trauma, infection, associated with gastrointestinal disorders, hormonal influences, emotional factors, auto-immunity, hematology factor, etc. ${ }^{3}$ In this case based on history and clinical examination, adjuvant examination, predisposing factors were most influential of this patient, emotional factors (stress) and auto-immune.

There is a suspicion of psychological stress, as in anamnesis further indicated that stress arising in connection with the pass away of one of the children of this patient. 


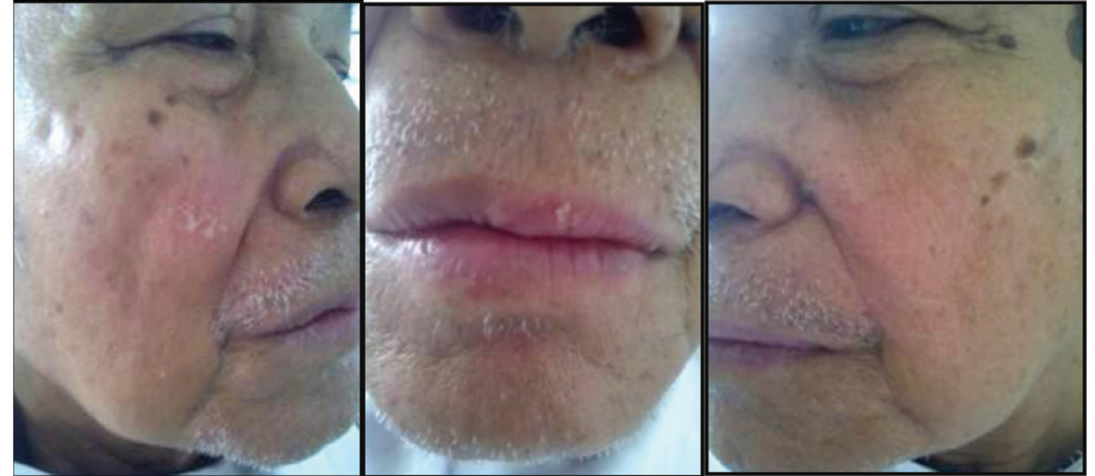

Figure 5 Extra-oral clinical photos at follow-up 1
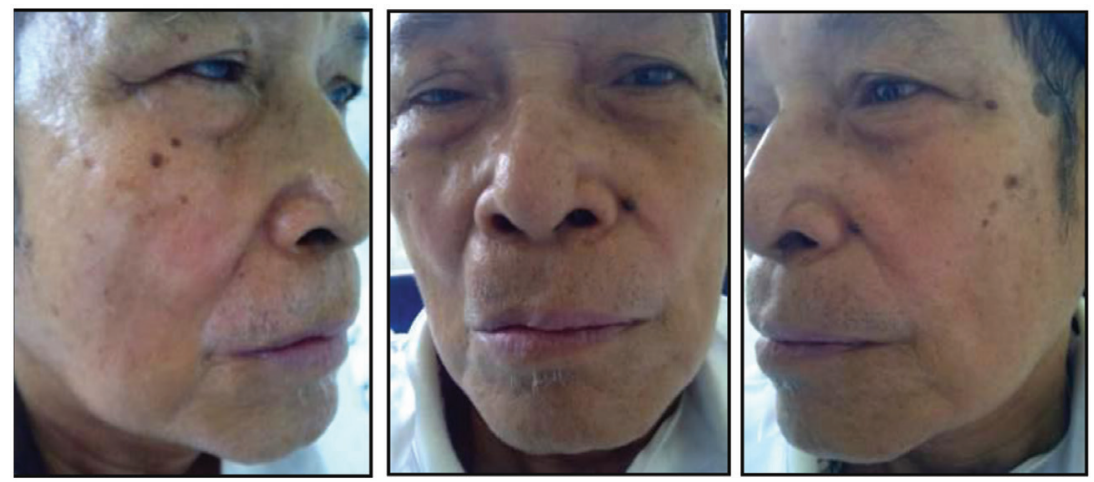

Figure 7 Extra-oral clinical photos at follow-up 2

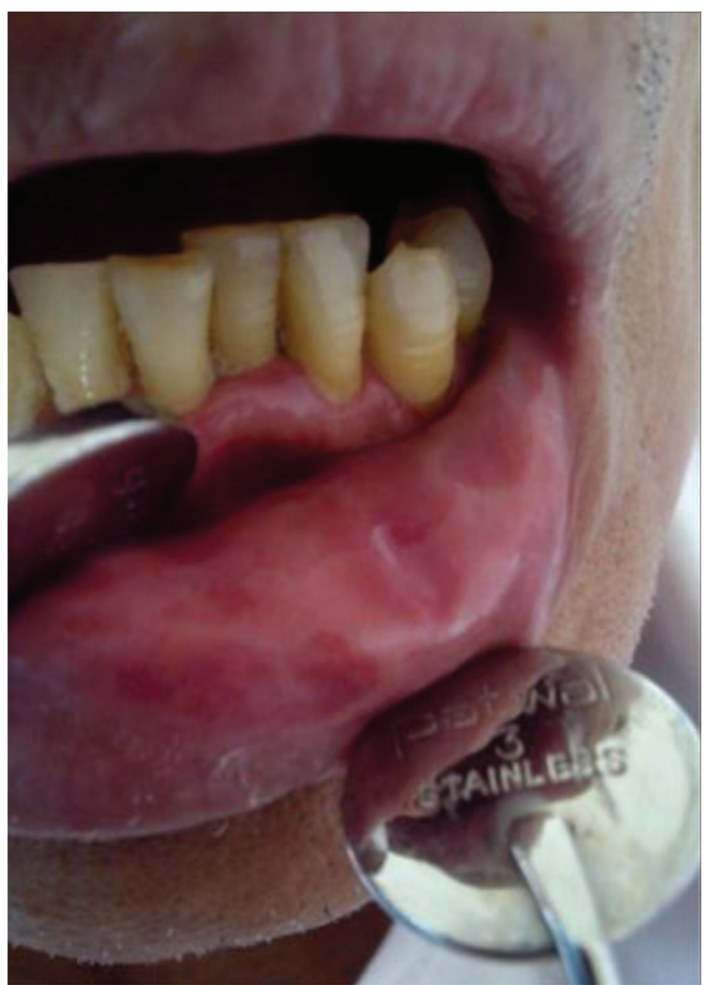

Figure 8 Intra-oral photos at follow-up 2

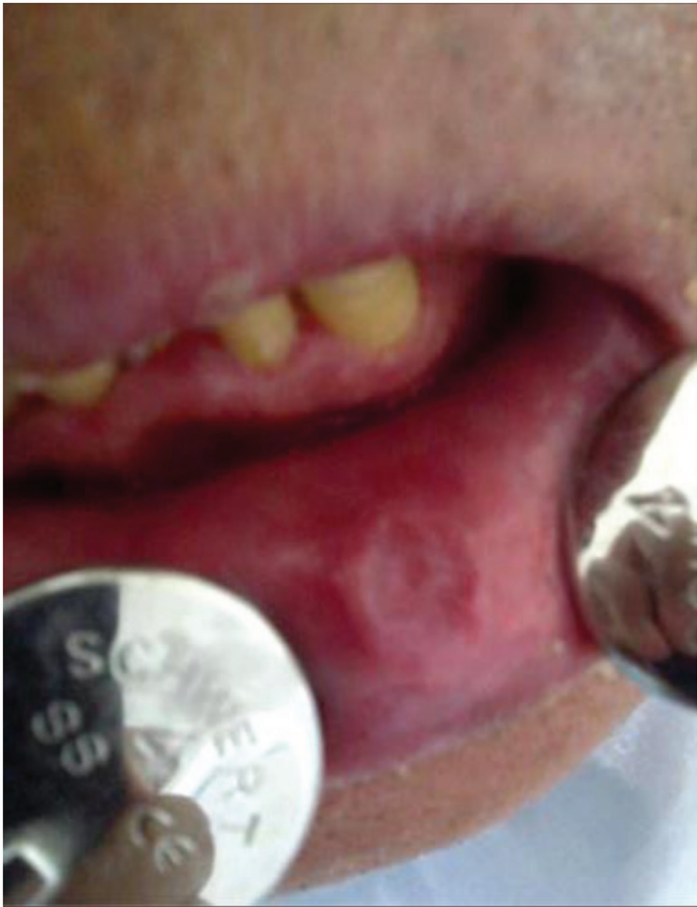

Figure 6 Intra-oral photos at follow-up 1

Other signs and symptoms associated with this condition reported in the literature include tingling, pain, pain in the mouth and throat, dry taste, ulceration, cracked and bleeding lips. ${ }^{5}$ Exfoliative cheilitis signs that have been mentioned are also felt by the patient.

Figure 5 at the first one week visit he followed treatment with visible progress, in the form of reduced desquamation of the lips and cheek area as well as inflammation of mucosal ulcers in the inner lips began to decrease, although still with pain.

Figure 6 on a visit one week after the first control based on history and clinical examination, treatment progress was very good. Based on the anamnesis, the patient had no complaint of pain around the face and in the mouth. Clinically apparent was the cheeks and the lips of patient, desquamation did not exist and color was like the surrounding tissue. Figure 7 in the second visit the patient was instructed to continue to use mouthwash and supplements to improve oral hygiene and increase endurance to suppress the frequency of recurrence of his RAS. It is also necessary to manage stress as predisposing factors either RAS or psoriasis figure 8 .

\section{Conclusion}

1. Stress is one factor besides the immune system which is very influential on the diseases suffered by this patient. Therefore the patient needs a good stress management to suppress 
recurrence of RAS, psoriasis and exfoliative cheilitis. Further, cooperation and appropriate prescribing are also necessary.

2. Patients and the public need information on predisposing factors of SAR hence the frequency of recurrence can be minimized. Controlling stress in patients SAR is indispensable where stress is one of the predisposing factors that are often experienced by patients.

3. General dentist is required to do careful treatment and observation to recognize all of the changes that occur both within and outside the oral cavity. Other disorders that require referral should be implemented with the cooperation in accordance with the relevant colleagues.

\section{References}

1. Scully C. Aphthous Ulceration. N Engl J Med 2006; 355: 165-172. Available from: URL: http://www.nejm.org/doi/ pdf/10.1056/NEJMcp054630.

2. Field A, Longman L. Oral ulceration. In Tyldesley's. Oral Medicine. 5th ed. Oxford: Oxford University Press; 2003. p. 52-53.

3. Rosarina A, Hendarti HT. Prevalensi stomatitis aftosa rekuren (SAR) yang dipicu oleh stres psikologis (di klinik penyakit mulut RSGM Fkg Unair September - Oktober 2009). Oral Medicine Dent J 2010;2: 30-33.
4. Favaretto LH, Lodi KB et al. Topical Calendula officina- lis L. successfully treated exfoliative cheilitis: a case report. Cases Journal 2009;2: 9077.5. Mani SA, Shareef BT. Exfoliative Cheilitis: Report of a Cas. JCDA 2007;73.

6. Menter A et al. Guidelines of care for the management of psoriasis and psoriatic arthritis: Section 1. Overview of psoriasis and guidelines of care for the treatment of psoriasis with biologics. J Am Acad Dermatol 2008: 828.

7. Scottish Intercollegiate Guidelines Network (SIGN). Diagnosis and management of psoriasis and psoriatic arthritis in adults. Edinburgh: SIGN; 2010. (SIGN publication no. 121). [cited 12 Oct 2010]: 1 Available from: URL: http://www.sign.ac.uk/pdf/sign121.pdf.

8. National Psoriasis Foundation. 1996-2014. Available from: http://www.psoriasis.org/about-psoriasis.

9. Kementerian Kesehatan Republik Indonesia. Pedoman Interpretasi Data Klinik. Jakarta: Kementerian Kesehatan Republik Indonesia; 2011. Available URL:http:// xa.yimg.com/kq/groups/19205602/2113109242/name/ PEDOMAN+INTERPRETASI+DATA+KLINIK.pdf.

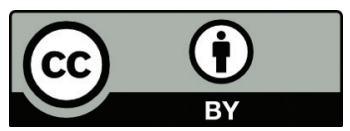

This work is licensed under a Creative Commons Attribution 